\title{
Barrier to contraceptive use among childbearing age women in rural Indonesia
}

\author{
Nikmatur Rohmah, Ah. Yusuf, Rachmat Hargono, Agung Dwi Laksono, Masruroh, Anita \\ Dewi Prahastuti Sujoso, llyas Ibrahim, Nur Baharia Marasabessy, Nasrun Pakaya, \\ Agustina Abuk Seran, Retno Adriyani, Saiful Walid \\ Rohmah N, Yusuf A, Hargono R, et al. Barrier to contraceptive use among childbearing age women in rural Indonesia. Malays Fam Physician. \\ 2021;16(3);16-22. https://doi.org/10.51866/oa1020
}

\section{Keywords:}

Barrier, contraceptive,

women of childbearing age,

rural

\section{Authors:}

Nikmatur Rohmah

(Corresponding author)

Dr. S.Kep., Ns. M.Kes.

Faculty of Health Science

Muhammadiyah University of Jember

East Java, Indonesia

Email:

nikmaturrohmah@unmuhjember.ac.id

\section{Ah. Yusuf}

Prof. Dr. S.Kp., M.Kes.

Faculty of Nursing, University of

Airlangga Surabaya, East Java

Indonesia

\section{Rachmat Hargono}

Dr. dr., M.S., M.PH.

Dept. of Health Promotion and

Behavior Sciences. Faculty of Public

Health, University of Airlangga

Surabaya, East Java, Indonesia

Agung Dwi Laksono

Dr. Bs.PH., MPH

National Institute of Health Research and Development, Indonesia Ministry of Health, Jakarta, Indonesia

Masruroh

S.Kep. Ns., M.Kes

Faculty of health science Universitas

Pesantren Tinggi Darul Ulum Jombang

East Java, Indonesia

\begin{abstract}
Introduction: The contraceptive prevalence rate in Indonesia has not experienced much improvement, which has led to an increase in the number of pregnancies. This study aimed to analyse the barriers to contraception use among women of childbearing age in rural Indonesia.

Methods: This study used a cross-sectional design with data from the Indonesian Demographic and Health Survey (IDHS) of 2017. The independent variables were age, employment status, education, marital status, wealth status, health insurance and parity. The dependent variable was the use of contraception. The statistical significance was set at $\mathrm{p}<0.05$ using bivariate analysis and binary logistic regression.

Results: The study showed that the age group of $45-49$ years (OR 0.199; 95\% CI 0.149-0.266), secondary education (OR 2.227; 95\% CI 2.060-2.514), women married/living with their partner (OR 43.752; 95\% CI: 35.484-53.946), wealth status: middle (OR 1.492; 95\% CI 1.400-1.589) and multipara (OR 2.524; 95\% CI: 2.328-2.737) exhibited the increased use of contraception among women of childbearing age in rural Indonesia.

Conclusion: The variables proven to represent obstacles to contraceptive use among women of childbearing age in rural Indonesia include old age, no education, no husband/partner, poverty and already having one child.
\end{abstract}

\section{Introduction}

Indonesia is a developing country that has population problems. Problems associated with Indonesia's population include a large population and a high level of population growth. ${ }^{1}$ One effort to control this population growth involves the use of a family planning programme. Family planning is a movement that aims to form healthy and prosperous families by limiting or planning the number of children through contraception. Contraception is a method or tool used to prevent pregnancy. Every woman of childbearing age has the right to choose a contraceptive method that works for them. ${ }^{2}$ The fundamental essence of reproductive health is to allow women to decide on the number of children they have and when they are born. ${ }^{3}$ The use of contraception in women of childbearing age is believed to support quality family formation. ${ }^{4}$

The problem is that the total fertility rate (TFR) in Indonesia has become stagnant over the last three decades. The TFR in Indonesia has reached 2.4 children per woman. This figure remains higher than the target of 2.3 children per woman for the 2015-2019 period. $^{3}$ In rural areas, the TFR, general fertility rate and crude birth rate are higher than those in urban areas at 2.6:2 overall ${ }^{3}$ and $85: 75,18.5$, and 17.5 , respectively. 5 Furthermore, the contraceptive prevalence rate (CPR) has not experienced much improvement.

Notably, the CPR fell from 57.6 in 2012 to 57.2 in 2017. This situation led to an increase in the number of pregnancies. The percentage of pregnant women in rural areas (4.1\%) was higher than in urban areas (3.7\%). Likewise, the percentage of children born in rural areas (3\%) was higher than in urban areas (2.6\%). ${ }^{5}$ Meanwhile, the rate of contraception use (all methods) increased from $27 \%$ in 2012 to $34 \%$ in 2017. ${ }^{3}$ Research on young women in rural areas has reported more obstacles when seeking to access contraception in comparison to urban areas. ${ }^{6}$ 
Anita Dewi Prahastuti Sujoso

Dr. S.KM., M.Sc

Public Health Faculty Jember

University, East Java, Indonesia

\section{Ilyas Ibrahim}

Dr. S.Psi.,M.Kes

Faculty of Health Science, Bumi

Hijrah Tidore University, North

Maluku, Indonesia

\section{Nur Baharia Marasabessy}

Dr. S.ST., M.Kes

Maluku Health Polytechnic

Ministry of Health, Ambon, Maluku

Indonesia

\section{Nasrun Pakaya}

Dr. S.Kep. Ns., M.Kep

Faculty of Sport and Health, State

University of Gorontalo, Gorontalo

Indonesia.

\section{Agustina Abuk Seran \\ S.Si.T., MPH \\ Doctoral Program, Faculty of Public \\ Health, University of Airlangga \\ Surabaya, Indonesia}

Kupang Health Polytechnic, Ministry of Health, Kupang, East Nusa

Tenggara, Indonesia

\section{Retno Adriyani}

ST. M.Kes.

Public Health Faculty Universitas Airlangga, East Java, Indonesia

\section{Saiful Walid}

S.Kep., Ners. M.MKes.

General Hospital dr H Koesnadi Bondowoso, East Java, Indonesia
The impact of contraceptive failure is an unwanted pregnancy. An unwanted pregnancy is an unhealthy pregnancy that can become a burden for women. Unplanned pregnancies are responsible for $90 \%$ of unwanted births. Overall, $17 \%$ of these pregnancies are a burden for the women and $89 \%$ end in unsafe abortions that threaten women's welfare. ${ }^{7}$ In 2010, the global abortion rate increased from 53 to $56 \%$. In Southeast Asia, it increased from 55 to $59 \% .{ }^{4}$ Unintended pregnancies will also increase the number of births.

The use of contraception in rural areas is lower than in urban areas. Moreover, the birth rate in rural areas is higher than in urban areas. The adverse effects of contraceptive failure for fertile women in rural areas are higher than for those in urban areas. Therefore, further analysis of the barriers to rural contraceptive use is required. As such, the present study analyses the barriers to contraception use among women of childbearing age in rural Indonesia. The findings in this study will help family planning policymakers by allowing them to devise strategies to minimise the barriers to contraceptive use for women of childbearing age in Indonesia's rural areas.

\section{Methods}

Study Design

This study used secondary data from the Indonesian Demographic and Health Survey (IDHS) in 2017. ${ }^{\circ}$ The survey was conducted in 34 provinces in Indonesia by the Central Statistics Agency, the National Population and Family Planning Agency, and the Ministry of Health of the Republic of Indonesia. Data collection occurred from July 24 to September 30, 2017.

\section{Sampling Methods}

The population consisted of women of childbearing age between 15 and 49 years old in Indonesia's rural areas. The sampling design used in the 2017 IDHS was stratified using two-stage sampling. Stage 1 involved selecting several census blocks in a systematic probability proportional to size (PPS), with the size of the number of households listed in 2010 population census. In this case, this was systematically performed using an implicit stratification process according to both urban and rural areas and by sorting out the census blocks based on the wealth index category from the SP2010 results. Stage 2 involved systematically selecting 25 households from each census block using the households' products in each census block. Furthermore, these results were used to identify women of reproductive age that were between 15 and 49 years old. The next selection stage involved selecting women who lived in rural areas. Overall, this process obtained 44,853 respondents.

The 2017 IDHS obtained ethical approval from the National Institute for Health Research and Development of the Indonesian Ministry of Health. All of the respondents' identities are unknown according to the data and the respondents gave written consent for their involvement in the research. Permission to use the 2017 IDHS in this study was obtained from ICF International on September 27, 2019, through its website (https://dhsprogram.com).

\section{Study Variables}

The dependent variable in this study was the use of contraception. The independent variables analysed as potential predictors included age group, employment status, education level, marital status, wealth status, health insurance ownership, and parity.

\section{Measures}

In this manuscript, the definition of rural is based on the categories of the Central Bureau of Statistics of Indonesia. The use of contraception is a tool/method used to regulate the time between pregnancies. The use of contraceptives is divided into two categories: use and no use. Contraceptive use includes traditional and modern contraception. The 15-49 years age group was divided into seven groups, with a reference age of 15-19 years. Employment status was split into two groups: working and not working. The reference was that they do not work. Education level consisted of four groups, specifically no education, primary education, secondary education and higher education. Marital status was divided into two groups: married/living with their partner and widowed/divorced/never in a union/no longer living together/separated. Wealth status is a person's socioeconomic status and describes their wealth level. Wealth level was divided into five groups: poorest, poorer, middle, richer and richest. Health insurance was split into two groups: having and not having health insurance. Parity was the number of deliveries, which was divided into three groups: multipara (2, 3 or 4$)$, grand multipara (4> labour) and primipara (1 delivery). 
Analysis

The first step in data analysis involved testing the relationship using the chi-squared test because all of the variables are dichotomous. In the final stage, the data analysis was performed using binary logistic regression.

\section{Results}

Table 1 presents the use of contraception in women of childbearing age in the rural areas of Indonesia. The women of childbearing age who used the most contraception (25.0\%) are in the age range of 35-39 years. From the perspective of work status, this was nearly the same since $61.4 \%$ of women worked and $61.1 \%$ did not work. The use of female contraceptives among those with a primary education totalled $47.0 \%$. The majority of women $(99.7 \%)$ who were married/lived with their partner used contraception. The wealth status phenomenon found that $51.3 \%$ of the poorest women did not use contraception. From the perspective of health insurance ownership, this number was balanced since $38.7 \%$ did not use contraception and 38.7\% did. Among multiparous women, 70.2\% used contraception. Several of the variables related to age, education level, marital status, wealth status and parity show a statistically significant relationship with the use of contraception for women of childbearing age in Indonesia's rural areas. However, the variables of employment status and health insurance were not proven to have a relationship with contraceptive use.

Table 1. Descriptive statistics of contraception use in women of childbearing age in the rural areas of Indonesia $(\mathrm{n}=44853)$.

\begin{tabular}{l|c|c|c|c}
\multirow{2}{*}{ Characteristics } & \multicolumn{2}{|c|}{ Contraception Use } & All & P \\
\cline { 2 - 4 } & No & Yes & & $<0.001^{* * *}$ \\
\hline Age group & & & & \\
$15-19$ (ref.) & $93(36.3 \%)$ & $163(63.7 \%)$ & $256(0.6 \%)$ & \\
$20-24$ & $650(33.0 \%)$ & $1322(67 \%)$ & $1972(4.4 \%)$ & \\
$25-29$ & $1603(35.1 \% \%)$ & $2963(64.9 \%)$ & $4566(10.2 \%)$ & \\
$30-34$ & $2440(32.0 \%)$ & $5190(68.0 \%)$ & $7630(17.0 \%)$ & \\
$35-39$ & $2926(30.0 \%)$ & $6830(70.0 \%)$ & $9756(21.8 \%)$ & \\
$40-44$ & $3930(37.8 \%)$ & $6472(62.2 \%)$ & $10402(23.2 \%)$ & \\
45-49 & $5941(55.4 \%)$ & $4330(44.6 \%)$ & $10271(22.9 \%)$ & \\
\hline Currently working & & & & \\
No (ref.) & $6790(39.0 \%)$ & $10620(61.0 \%)$ & $17410(38.8 \%)$ & \\
Work & $10793(24.1 \%)$ & $16650(75.9 \%)$ & $27443(61.2 \%)$ & \\
\hline Education & & & & \\
No education (ref.) & $1523(65.5 \%)$ & $802(34.5 \%)$ & $2325(5.2 \%)$ & \\
Primary & $8611(40.2 \%)$ & $12804(59.8 \%)$ & $21415(47.7 \%)$ & \\
Secondary & $6312(35.1 \%)$ & $11682(64.9 \%)$ & $17994(40.1 \%)$ & \\
Higher & $1137(44.7 \%)$ & $1982(55.3 \%)$ & $3119(7.0 \%)$ & \\
\hline Marital status & & & & \\
Married/living with partner & $15130(35.8 \%)$ & $27177(64.2 \%)$ & $42307(94.3 \%)$ & \\
Widowed/divorced (ref.) & $2453(96.3 \%)$ & $93(3.7 \%)$ & $2546(5.7 \%)$ & \\
\hline Health Insurance & & & & \\
No (ref.) & $6798(39.2 \%)$ & $10541(60.8 \%)$ & $17339(38.7 \%)$ & \\
Yes & $10785(39.2 \%)$ & $16729(60.8 \%)$ & $27514(61.3 \%)$ & \\
\hline Parity & & & & \\
Primipara (ref.) & & & \\
Multipara & $9664(33.6 \%)$ & $19143(66.4 \%)$ & $28807(64.2 \%)$ & \\
Grand multipara & $5925(49.8 \%)$ & $5977(50.2 \%)$ & $11902(26.5 \%)$ & \\
\hline Note:**** & & & \\
\hline
\end{tabular}

Note: ${ }^{*} \mathrm{p}<0.05 ;{ }^{* *} \mathrm{p}<0.01 ;{ }^{* * *} \mathrm{p}<0.001$. 
Table 2. Binary logistic regression for contraception use in women of childbearing age in the rural areas of Indonesia $(\mathrm{n}=44853)$.

\begin{tabular}{l|c|c|c|c}
\multirow{2}{*}{ Determinants } & \multicolumn{4}{|c}{ Contraception Use } \\
\cline { 2 - 5 } Age group: 20-24 & Sig. & OR & Lower bound & Upper bound \\
\hline Age group: 25-29 & 0.091 & 0.776 & 0.579 & 1.042 \\
\hline Age group: 30-34 & $<0.001^{* * *}$ & 0.511 & 0.383 & 0.681 \\
\hline Age group: 35-39 & $<0.001^{* * *}$ & 0.504 & 0.378 & 0.673 \\
\hline Age group: 40-44 & $<0.001^{* * *}$ & 0.575 & 0.431 & 0.768 \\
\hline Age group: 45-49 & $<0.001^{* * *}$ & 0.429 & 0.322 & 0.573 \\
\hline Education: Primary & $<0.001^{* * *}$ & 0.199 & 0.149 & 0.266 \\
\hline Education: Secondary & $<0.001^{* * *}$ & 2.226 & 2.022 & 2.451 \\
\hline Education: Higher & $<0.001^{* * *}$ & 2.276 & 2.060 & 2.514 \\
\hline Marital status: Married/living with partner & $<0.001^{* * *}$ & 43.752 & 35.484 & 53.946 \\
\hline Wealth status: Poorer & $<0.001^{* * *}$ & 1.382 & 1.310 & 1.459 \\
\hline Wealth status: Middle & $<0.001^{* * *}$ & 1.492 & 1.400 & 1.589 \\
\hline Wealth status: Richer & $<0.001^{* * *}$ & 1.426 & 1.324 & 1.535 \\
\hline Wealth status: Richest & $<0.001^{* * *}$ & 1.489 & 1.349 & 1.643 \\
\hline Parity: Multipara & $<0.001^{* * *}$ & 2.524 & 2.328 & 2.737 \\
\hline Parity: Grand multipara & $<0.001^{* * *}$ & 1.840 & 1.677 & 2.019 \\
\hline Note:*P & & & &
\end{tabular}

Note: ${ }^{*} \mathrm{p}<0.05 ;{ }^{* *} \mathrm{p}<0.01{ }^{* * *} \mathrm{p}<0.001$.

The statistical test results from using multinomial logistic regression show that the R2 coefficient, which was marked by a Nagelkerke value of $16.1 \%$, indicates that the analysed variables could explain $83.9 \%$ of the variability in contraception use. Other factors outside the model can explain the remaining variability. Logistic regression analysis does not require the assumption of linearity between the variables in addition to multivariate normality, homoscedasticity and homogeneity (either dichotomous or multinomial). The categories must be separate from one another and exclusive to allow for the selection of relationships to predict the odds ratio.

Table 2 illustrates the binary logistic regression test results for contraceptive use among women of childbearing age in rural Indonesia. The reference is 'non-user' and the use of contraception in women of childbearing age is as follows. The 45-49 year age group is 0.199 times more likely to use contraception than the 15-19 year age group. Women with a secondary level of education are 2.227 times more likely than uneducated women to use contraception. Women who are married/living with a partner are 43.752 times more likely to use contraception than women who are widowed/divorced. Middleclass women are 1.492 times more likely to use contraception when compared to the poorest women. Multiparous women are 2.524 times more likely to use contraception than primiparous women.

\section{Discussion}

Among women of reproductive age in rural Indonesia, the present study indicates that the 15-19 year age group has the highest probability of using contraception. The older the women are, the less likely they are to use contraception. The results of this study are similar to the results of studies examining the use of contraceptives in Nepal, Africa and Nigeria. ${ }^{9,10}$ These results indicate that the youngest age group is serious about planning/ regulating their pregnancy spacing. This could be due to the risk of pregnancy among young women being higher. The risk associated with sexual activity in younger women is higher than that of older women. Data from the Journal of Sexual Medicine suggest that the most sexually active age is $18-29$. In the later age groups, the quantity of sexual intercourse decreases. ${ }^{11}$

Regarding the use of contraceptives, the results of this study differ from those of women in several other countries. Women of Childbearing age in Canada, Ethiopia, NorthWestern Tanzania, the USA and Nigeria also indicate that contraception use increases with age. ${ }^{12-16}$ If a woman wants to avoid pregnancy, 
contraception is still required-even when the woman is older. ${ }^{17}$ For a woman in her reproductive period, increasing age means that she is generally concentrated more on childcare tasks and does not want to have more children.

Differences in the effect of age on contraceptive use in several countries indicate that other factors also play a role in contraceptive use. These factors include culture and beliefs. The diversity of cultures and beliefs in each country is different and will influence women's decisions to use contraception.

Middle-educated women of reproductive age in rural Indonesia are most likely to use contraception. The less educated a woman of reproductive age is, the less likely she will be to use contraception. This study supports previous findings from Africa, Nepal and Ethiopia. ${ }^{9,10,12,18,19}$ Education is a planned and formal learning process. A person with more education will be exposed to a lot of scientific information. Moreover, a person's awareness of their own health needs becomes more prominent if they have better health knowledge. A higher education level among women of childbearing age can be related to more exposure to information about women's reproductive health..$^{20,21}$ One of the actions involved in caring for reproductive health is the use of contraception. Thus, it can be understood that higher education increases the interest in maintaining reproductive health by using contraception. Women with a higher level of education tend to discuss contraceptive use with their partners. The result is a joint decision. Decisions resulting from mutual decisions will impact decision satisfaction and result in a higher commitment to contraceptive use.

This study indicates that education increases women's awareness of responsibly maintaining their reproductive health. Notably, the use of contraception is the result of this awareness. As such, the higher the education level of women, the higher their chance of using contraception.

This study indicates that women of reproductive age in rural Indonesia who are married/living with their partner have a higher likelihood of using contraception than widowed/divorced women. This study supports the findings of Women of
Childbearing age in Canada, Ethiopia, the USA and Africa. ${ }^{10,12,15,18}$ Women who are married or living with their partners feel more secure and comfortable in terms of sexual intercourse. This context has an impact on active sexual relations, which can be performed at any time and as often as possible in natural situations. Since every act of sexual intercourse will have the potential for pregnancy, women who are married are more likely to use contraception to adjust their pregnancy spacing.

This study also reinforces the belief that good sexual relations are carried out in a legal marriage. Sexual intercourse that impacts pregnancy can be prevented through the use of contraception. The use of contraception in a legal marriage will perpetuate sexual relations because it can regulate pregnancy spacing.

This study indicates that women of childbearing age and middle wealth status in the rural areas of Indonesia are the most likely to use contraception. Conversely, the poorest women of childbearing age are increasingly not using contraception. These results are in line with findings focused on women of childbearing age in Africa. ${ }^{10,22}$ Average wealth has a positive and significant effect on the use of modern contraception. ${ }^{23}$ In light of the various tools and methods possible, the use of contraception costs money. Some contraceptive methods require fees that must be provided continuously every month, three months or 2 to 3 years, whilst others require a one-time fee. However, contraception is not always financed by health insurance. Thus, all women must have a budget allocated for contraceptive use. The richest women are freer to determine their contraception choices according to their health status, whereas the poorest woman must adjust according to their budget.

This study has identified the barriers to contraceptive use for women of reproductive age in rural Indonesia. The highest level of contraceptive use was associated with married and multiparous status. The groups most vulnerable to not using contraception are the 15-19 year age group, the uneducated and the poorest. Additional barriers to contraceptive use in Indonesia include perceptions and the contraceptive services available to women. A study conducted in West Nusa Tenggara, Indonesia showed that 
perceptions regarding the side-effects of contraceptive methods, ease of contraception use and cost of contraceptives relate to the rational pattern of switching contraceptive methods. ${ }^{24}$ Notably, a survey performed in Bali, Indonesia found that the utilisation of family planning services was low. ${ }^{25}$

Based on the results of the present study, the most vulnerable groups that require special attention in terms of family planning use in Indonesia are young women who are uneducated and poor. The familybased Indonesia Sehat programme is expected to reduce the disparities in access to contraceptive use. Indonesia's cultural diversity and territory (i.e., an archipelago) represent challenges for the programme implementers. Community involvement and cooperation between the government and WUS are required to achieve high levels of contraceptive use in Indonesia.

\section{Limitations and Strengths}

The principal strength of this study is that it provides policymakers with information about the factors that have become barriers to the use of contraception for women of childbearing age in the rural areas of Indonesia. With its family approach, the Healthy Indonesia Programme is the main programme for health development in Indonesia. Disparities in health development-especially in terms of healthy family indicators - remain present throughout the Indonesian territory. One indicator of a healthy family that requires greater attention is family planning among married women aged 15 to 49 years. Therefore, the use of family planning at the WUS in Indonesia's rural areas should be a concern. One limitation of this study is that it only focuses on rural women in regions within Indonesia that have archipelagic characteristics and diverse tribes. Therefore, the results cannot be generalised to rural areas in other countries with different demographic characteristics. Moreover, the use of a cross-sectional approach makes it impossible to make conclusions regarding the temporality of the association. Furthermore, this research only focuses on demographic characteristics and does not consider other factors related to the social support systems of women. Therefore, it is necessary to conduct further research on contraception in urban and rural areas by involving determinants related to social support system variables.

\section{Conclusions}

Five variables have been identified as barriers to contraception use among women of childbearing age in rural Indonesia. The five factors include old age, no education, no husband/partner, poverty and already having one child.

\section{Acknowledgements}

The authors would like to thank the International ICF Institute, which approved the analysis of data from the IDHS 2017. We would also like to thank the Educational Fund Management Agency of the Ministry of Finance of the Republic of Indonesia.

\section{Conflicts of Interest}

The authors declare there to be no potential conflicts of interest concerning the research, authorship and publication of this article.

\section{How does this paper make a difference to general practice?}

1. This study highlights the strategy and policies of the Healthy Indonesia Programme and suggests that a family approach should be used to target the rural WUS group.

2. This study notes the urgent need for further research and refined policy strategies to ensure that these vulnerable groups can obtain improved access to contraceptive services. 


\section{References}

1. Wijayati H. Population Problem in Indonesia (Masalah Kependudukan di Indonesia) [Internet]. Course Hero; 2017 [cited 2020 Jan 2]. Available from: https://www.coursehero. com/file/46564783/Analisis-MasalahKepndudukan-2docx/.

2. Government Regulation Republic of Indonesia. Government Regulation 61 of 2014 concerning Reproductive Health [Internet]. JDIH - Jaringan Dokumentasi dan Informasi Hukum; 2014 [cited 2020 Jan 2]. Available from: https://peraturan.bpk.go.id/Home/ Details/5502/pp-no-61-tahun-2014.

3. Ekoriano M, Rahmadhony A, Prihyugiarto TY, et al. Hubungan pembangunan keluarga dan pemakaian kontrasepsi di Indonesia. $J \mathrm{Kel}$ Berencana. 2020;5:1-15.

4. Ardiana, I, Ekoriano M, Fathonah S. Unwanted Birth Relationship to the Family Planning Program in Indonesia, SKAP 2018 Data Analysis (Kelahiran yang tidak diinginkan hubungannya dengan program Keluarga Berencana di Indonesia Analisis Data SKAP 2018). Puslitbang KB dan KS; 2019 [cited 2020 Jan 2]. Available from: https://cis.bkkbn. go.id/latbang/?wpdmpro=kelahiran-yang-tidakdiinginkan-dan-hubungan-dengan-programkb-di-indonesia_mario-e.

5. BKKBN BPS, Kementerian Republik Indonesia, USAID. Indonesian Demographic and Health Survey 2017 (Survei Demografi dan Kesehatan Indonesia 2017). Central Bureau of Statistics of the Ministry of Health (Badan Pusat Statistik Kementerian Kesehatan); 2018. ISBN 978-602-316-139-3

6. Geske S, Quevillon R, Struckman-Johnson C, et al. Comparisons of contraceptive use between rural and urban teens. J Pediatr Adolesc Gynecol. 2015;29:33-41.

7. Diasanty Nurlaely P, Sutiawan R. Contraceptive Failure with the Incidence of Unwanted Pregnancy (UP) in High Risk Age Women in Indonesia (Further Analysis of the 2012 IDHS Data) (Kegagalan kontrasepsi dengan kejadian kehamilan tidak diinginkan (KTD) pada Wanita Usia Berisiko Tinggi di Indonesia. http://lib.ui.ac.id/ 1-18; 2014 [cited 2020 Jan 20]. Available from: https://adoc.pub/ kegagalan-kontrasepsi-dengan-kejadiankehamilan-tidak-diingi.html.
8. BKKBN, BPS, Kementerian Kesehatan RI, \& ICF, 2017 Indonesia Demographic and Health Survey. BPS, BKKBN, Kemenkes and ICF International; 2017. ISBN 9786023161393

9. Bhandari R, Pokhrel KN, Gabrielle N, et al. Long acting reversible contraception use and associated factors among married women of reproductive age in Nepal. PLoS One. 2019;14:1-13.

10. Adedini SA, Omisakin OA, Somefun, OD. Trends, patterns and determinants of longacting reversible methods of contraception among women in sub-Saharan Africa. PLoS One. 2019;14:1-16.

11. Gunawan H. Here is the frequency of sex based on age (ini dia frekuensi hubungan seks berdasarkan usia) 1; 2017 [cited 2021 Jan 15]. Available from: https://kesehatan.kontan.co.id/ news/ini-dia-frekuensi-jual-sex-berdasarkanusia.

12. Finnsdottir M, Wu Z. Contraceptive use in Canada, 2001 to 2011. Can Stud Popul. 2019;46:27-46.

13. Habtamu A, Tesfa M, Kassahun M, et al. Determinants of long-acting contraceptive utilization among married women of reproductive age in Aneded district, Ethiopia: A case-control study. BMC Res Notes. 2019;12:1-6.

14. Nsanya MK, Atchison CJ, Bottomley C, et al. Modern contraceptive use among sexually active women aged 15-19 years in North-Western Tanzania: Results from the Adolescent 360 (A360) baseline survey. BMJ J. 2019;9:1-11.

15. Mosher WD, Moreau C, Lantos H. Trends and determinants of IUD use in the USA, 2002-2012. Hum Reprod. 2016;31:1696-702.

16. Banjo OO, Olusina SB, Luqman AB, et al. Decision making autonomy and fertility behaviour among currently married women in Nigeria. African Popul Stud. 2018;32:1-4.

17. CDC. Contraceptive Guidance For Health Care Providers. 2017.Centers for Disease Control and Prevention can be accessed via https://www.cdc.gov/reproductivehealth/ contraception/contraception_guidance.htm
18. Moges Y, Hailu T, Dimtsu B, et al. Factors associated with uptake of post-abortion family planning in Shire town, Tigray, Ethiopia. BMC Res Notes. 2018;11:1-6.

19. Ngoa N, Brice G. Female education and contraception choice: Evidence from Cameroon. J Econ Dev Stud. 2018;6:143-53.

20. Rohmah N, Yusuf Ah, Hargono R, et al. Determinants of teenage pregnancy in Indonesia. Indian J Forensic Med Toxicol. 2020;14:2080-5.

21. Seran AA, Antaria MD, Haksama S, et al. Disparities of the use of hormonal and nonhormonal contraceptive drugs in urban and rural areas in Indonesia and the world. Syst Rev Pharm. 2020;11:66-73.

22. Ugaz JI, Chatterji M, Gribble JN. Is household wealth associated with use of long-acting reversible and permanent methods of contraception? A multi-country analysis. Glob Heal Sci Pract. 2016;4:43-54.

23. Dias JG, de Oliveira IT. Multilevel effects of wealth on women's contraceptive use in Mozambique. PLoS One. 205;10:1-15.

24. Amran Y, Nasir NN, Dachlia D, et al. Perceptions of contraception and patterns of switching contraceptive methods among family-planning acceptors in West Nusa Tenggara, Indonesia. J Prev Med Pub Health. 2019;52:258-264.

25. Ani LS, Merdana IM, Sumiati N. Family planning services at Denpasar toward a healthy city. J Pengemb Kota. 2019;7:120-7. 